)

ACHNR

\section{Asian Community Health Nursing Research}

Asian Comm. Health Nurs. 2021, 3(2), 1-6

\title{
Determinant of Anxiety Levels among Pregnant Women during Covid-19 Pandemic
}

\author{
Shinta Novelia*, Rosmawaty Lubis, and Reni Apryanti \\ Midwifery Department, Faculty of Health Sciences, Universitas Nasional Jakarta \\ *Correspondence: shinta.novelia@civitas.unas.ac.id \\ Type of the Paper (Article) \\ Received: July 5, 2021; Accepted: August 15, 2021; Published: September 9, 2021 \\ https://doi.org/10.29253/achnr.2021.3665
}

\begin{abstract}
In Indonesia, 107,000 pregnant women experience anxiety in facing labor. Based on a preliminary study conducted on 7 respondents, 7 said they worried about getting pregnant during the Covid-19 pandemic because they were fearful of being exposed to the Covid-19 virus and could threaten pregnant women. The objective was to determine the factors related to the anxiety of pregnant women during the Covid19 pandemic in the Banjar Pandeglang Health Center work area in 2021. The study used a crosssectional design. The population was a total population with an accidental sampling technique; 112 pregnant women were enrolled with inclusion and exclusion criteria. There was a significant relationship between knowledge p-value (0.004), family support $(0.000)$ and health facilities $(0.003)$ with the level of anxiety of pregnant women during the Covid-19 pandemic in the Banjar Health Center work area Pandeglang. There was no relationship between health information and the level of anxiety of pregnant women during the Covid-19 pandemic. It is hoped that pregnant women can pay more attention to their condition both physically and psychologically and ask their husbands or families to continuously provide support, maintain pregnancy, prepare for childbirth, and still comply with health protocols to avoid the Covid-19 virus.
\end{abstract}

Keywords: anxiety; family support; health facilities; health information; knowledge; pregnant women

\section{Introduction}

On December 31, 2019, China reported a case of pneumonia of unknown cause. Initially, this case was reported in the Wuhan area, Hubei Province. In three days, the number of patients with these cases was 44 people and continues to grow until now there are thousands of cases. Coronavirus disease 2019 (COVID-19) is a disease that is currently endemic almost all around the world, caused by Severe Acute Respiratory Syndrome Coronavirus-2 (SARS-CoV-2). Although initially this virus was given the name Novel Coronavirus (2019-nCoV) on February 11, 2020, the World Health Organization (WHO) named the new virus Severe Acute Respiratory Syndrome Coronavirus-2 (SARS-CoV-2) and called the disease Coronavirus disease 2019 (COVID-19) (WHO, 2020).

On January 30, 2020, WHO was declared COVID-19 as a Public Health Emergency of Concern for the World. Furthermore, on March 11, 2020, Covid-19 was declared a pandemic which means Covid-19 has spread to several countries or continents, infecting many people. As a result of these conditions and the process of extending that is not limited to a particular population or country, causing increased stress 
and anxiety. It is also inseparable from the people of pregnant women. Anxiety is the most common emotional problem in pregnancy. Anxiety in pregnant women can affect pregnancy, such as premature labor, stunted fetal growth, neurodevelopment, and poor behavior (WHO, 2020).

Common signs and symptoms of COVID-19 infection can include asymptomatic, mild, moderate, to severe symptoms. The main clinical symptoms are fever (temperature $>38^{\circ} \mathrm{C}$ ), cough, and difficulty breathing. The average incubation period is 5-6 days, with the most prolonged most extended incubation period being 14 days. In severe cases of COVID-19, it can cause pneumonia, acute respiratory syndrome, kidney failure, and even death. There is still no evidence that pregnant women are more at risk of contracting COVID-19 than the general population. However, due to changes in the body and immunity, it is believed that pregnant women have a higher risk of serious illness, morbidity, and mortality compared to the general population if exposed to COVID-19. Until now, knowledge about COVID-19 infection concerning pregnancy and the fetus is still limited and there are no specific recommendations for treating pregnant women with COVID-19. In addition, side effects on the fetus in the form of preterm delivery have also been reported in pregnant women with COVID-19 infection (Kemenkes RI, 2020).

Anxiety will have negatively impact pregnant women from pregnancy to delivery, inhibiting growth, depleting uterine muscle contractions, and others. These impacts can harm the mother and fetus (Novitasari, 2013). A study in Indonesia shows that pregnant women with high anxiety levels risk giving birth to premature babies and even miscarriages (Astria, 2019). In addition to impacting the delivery process, anxiety in pregnant women can also affect the growth and development of children. Stress that occurs mainly in the third trimester can lead to a decrease in birth weight (Shahhosseini et al., 2015).

Corona Virus does not have a particular specific on pregnancy. In the UK, 472 pregnant women were hospitalized with Corona Virus with their babies during the pandemic. Some of the women in the study required only ordinary routine care and were discharged in good condition, about one in ten women required intensive care and five women died, although it is not yet known whether the virus was the cause of death. Until now, no research has found a drug or vaccine for the Covid-19 virus (UKOSS, 2020). This virus is new, so no evidence shows an increased risk of miscarriage. However, evidence suggests that mother-to-child transmission may occur during pregnancy or birth (Vertical Transmission). All over the world, there are reports that some babies are born prematurely to some unwell mothers with Corona Virus. But it is not clear whether this virus causes premature birth (UKOSS, 2020). Research in the UK shows that in one out of five babies born prematurely and admitted to the neonatal unit, fewer than 20 babies are born very prematurely. Transmission of Corona Virus infection from mother to baby is low (UKOSS, 2020).

Based on the results of previous research conducted by Astuti (2012) in a study that related the characteristics of pregnant women in the third trimester to the level of anxiety at Pasar Rebo Hospital, it was stated that of the 47 respondents studied, 93.6\% experienced mild anxiety and $6.4 \%$ experienced severe stress. The results of research by Hernanto (2016) found pregnant women experience anxiety about a delivery, and (48\%) experienced intense extreme levels of anxiety. A previous study revealed that the COVID-19 pandemic induces a doubling of the number of women who reached abnormal levels of anxiety (Mappa, Distefano, \& Rizzo, 2020). Based on a preliminary study conducted on ten respondents, 7 of them said they felt anxious about getting pregnant during the Covid-19 pandemic. This was because the mother was afraid of being exposed to the Covid-19 virus, which could endanger her current pregnancy. Based on the description above, the researcher will conduct a study entitled "Factors related to the anxiety of pregnant women during the Covid-19 pandemic in the working area of the Banjar Pandeglang Health Center in 2021".

\section{Method}

The research design used in this study was cross-sectional. The population was 112 pregnant women in January in the working area of the Banjar Health Center. The sample was total population (112 pregnant women) with an accidental sampling technique based on the inclusion and exclusion criteria. The inclusion criteria are women who agreed joining the study, no pregnancy/ labor complication. While the exclusion criteria are women with pregnancy/ labor complication.

The variables are anxiety levels, knowledge, family supports, health care facility, and health information. A questionnaire has been developed by the researcher using KAP (Knowledge, Attitude and Practice) theory. The questionnaire including knowledge, family supports, and health care facility. It has 
been tested for validity and reliability (Cronbach alpha $=0.87$ ). The knowledge was categorized by mean to be good and poor, the family support was categorized by mean to be not supported and supported, the health facility was categorized by mean to be un accessible and accessible, and health information was categorized by mean to be poor and good. The Hamilton Anxiety Rating Scale was used to assess the anxiety. The data collection procedure has been conducted in the Banjar Health Centre for 4 weeks. All trimester III pregnant women who visited Banjar Health Centre and met the inclusion and exclusion criteria were delivered the questionnaire. Then they were asked to fill the questionnaire for 60 minutes. The researcher collected all questionnaire that has been filled. The data were analyzed by inferential statistic by a square test. This research has gained approval from the Universitas Nasional with the letter Number 035/D/SP/FIKES/2021 and Banjar Health Centre with the letter Number 800/PKM/Bjr/II/2021. Data were analyzed by descriptive and inferential statistic.

\section{Results}

The results of this current study are presented in following Table 1 and Table 2.

Table 1. Frequency distribution of all variables.

\begin{tabular}{|c|c|c|}
\hline Variable & f & (\%) \\
\hline \multicolumn{3}{|l|}{ Anxiety levels } \\
\hline Low & 20 & 17.9 \\
\hline Moderate & 54 & 48.2 \\
\hline Severe & 38 & 33.9 \\
\hline \multicolumn{3}{|l|}{ Knowledge } \\
\hline Poor & 47 & 42.0 \\
\hline Good & 65 & 58.0 \\
\hline Family support & & - \\
\hline Not supported & 51 & 45.5 \\
\hline Supported & 61 & 54.5 \\
\hline Health facility & & - \\
\hline Inaccessible & 38 & 33.9 \\
\hline Accessible & 74 & 66.1 \\
\hline Health information & & - \\
\hline Poor & 59 & 52.7 \\
\hline Good & 53 & 47.3 \\
\hline
\end{tabular}

Based on Table 1 shows that out of the 112 pregnant women respondents, 54 respondents (48.2\%) had moderate anxiety, 65 respondents (58\%) had good health knowledge during the Covid-19 pandemic, 61 respondents (54.5\%) did not get family supports, 74 pregnant women $(66.1 \%)$ stated the inaccessible of health facilities and 59 respondents (52.7\%) had poor health information during the Covid-19 pandemic.

Out of the 65 respondents with good knowledge, $46.2 \%$ respondents experienced severe anxiety levels, while from 47 respondents with poor knowledge, 27 respondents (57.4\%) experienced moderate anxiety. Therefore, from the statistical test obtained p-value $(0.004<0.05)$, it can be said that there was a relationship between knowledge and anxiety of pregnant women during the Covid-19 pandemic in the working area of the Banjar Pandeglang Health Center.

Out of the 61 respondents who received support from their families, 39 respondents (63.9\%) experienced moderate anxiety levels. Meanwhile, out of the 51 respondents who did not get support from their families, 27 respondents (52.9\%) experienced severe anxiety. Therefore, from the statistical test obtained p-value $(0.000<0.05)$, it can be said that there was a relationship between family support and anxiety of pregnant women during the Covid-19 pandemic in the work area of the Banjar Pandeglang Health Center.

Out of the 74 respondents with accessible health facilities, most respondents (56.8\%) experienced moderate anxiety levels, while from 38 respondents with inaccessible health facilities, 21 respondents $(55.3 \%)$ experienced severe anxiety. Therefore, from the statistical test obtained p-value $(0.003<0.05)$, it can be said that there was a relationship between health facilities and the anxiety of pregnant women during the Covid-19 pandemic in the work area of the Banjar Pandeglang Health Center. 
Out of 53 respondents with good health information, 24 respondents (45.3\%) experienced moderate anxiety levels, while from 59 respondents with poor health information, 30 respondents $(50.8 \%)$ experienced mild anxiety. Therefore, from the statistical test obtained p-value $(0.456)>(0.05)$, it can be concluded that there was no relationship between health information and anxiety of pregnant women during the Covid-19 pandemic in the working area of the Banjar Pandeglang Health Center.

Table 2. Factors related to level of anxiety for pregnant women during Covid-19 pandemic.

\begin{tabular}{|c|c|c|c|c|c|c|c|c|c|}
\hline \multirow{3}{*}{ Variable } & \multicolumn{6}{|c|}{ Anxiety levels } & \multirow{2}{*}{\multicolumn{2}{|c|}{ Total }} & \multirow{3}{*}{$p$} \\
\hline & \multicolumn{2}{|c|}{ Low } & \multicolumn{2}{|c|}{ Moderate } & \multicolumn{2}{|c|}{ Severe } & & & \\
\hline & $\mathbf{N}$ & $\%$ & $\mathbf{N}$ & $\%$ & $\mathbf{N}$ & $\%$ & $\mathbf{N}$ & $\%$ & \\
\hline \multicolumn{10}{|l|}{ Knowledge } \\
\hline Poor & 12 & 5.5 & 27 & 57 & 8 & 17 & 47 & 100 & \multirow{2}{*}{0.004} \\
\hline Good & 8 & 2.3 & 27 & 42 & 30 & 46 & 65 & 100 & \\
\hline \multicolumn{10}{|l|}{ Family support } \\
\hline Not supported & 9 & 17.6 & 15 & 29 & 27 & 53 & 51 & 100 & \multirow{2}{*}{0.000} \\
\hline Supported & 11 & 18.0 & 39 & 64 & 11 & 18 & 61 & 100 & \\
\hline \multicolumn{10}{|l|}{ Health facility } \\
\hline Not accessible & 5 & 13.2 & 12 & 32 & 21 & 55 & 38 & 100 & \multirow{2}{*}{0.003} \\
\hline Accessible & 15 & 20.3 & 42 & 57 & 17 & 23 & 74 & 100 & \\
\hline \multicolumn{10}{|l|}{ Health information } \\
\hline Poor & 12 & 20.3 & 30 & 51 & 17 & 29 & 59 & 100 & \multirow{2}{*}{0.456} \\
\hline Good & 8 & 15.1 & 24 & 45 & 21 & 40 & 53 & 100 & \\
\hline
\end{tabular}

\section{Discussion}

The results showed that there was a relationship between knowledge and anxiety of pregnant women during the Covid-19 pandemic in the working area of the Banjar Pandeglang Health Center. Knowledge will determine and influence a person's attitude in dealing with pregnancy and childbirth. Knowledge about pregnancy and childbirth has an essential vital role in the preparation of pregnant women in the face of childbirth later, so that mothers do not feel anxious and can enjoy the process of delivery. The unpreparedness of pregnant women is the results from something they do not know or lack of information about pregnancy and childbirth, especially for primigravida women, where they do not have experience of pregnancy and childbirth (Masruroh, 2019).

Based on research conducted by Walangadi with the title The relationship between knowledge of primigravida pregnant women in the third trimester with maternal anxiety levels facing childbirth at the MCH polyclinic at Tuminting Health Center in (2014), the study showed that the knowledge of primigravida pregnant women with maternal anxiety levels in facing delivery got a $\mathrm{p}$ value $=0.000$ which means there was a relationship between the knowledge of primigravida pregnant women in the third trimester and the level of maternal anxiety facing childbirth at the Tuminting Health Center KIA poly with the value obtained $(\mathrm{p}=0.0000 .05)$. Therefore, this study results show that pregnant women who have good knowledge have severe levels of anxiety compared to pregnant women who have poor knowledge because pregnant women who have good knowledge are always looking for information related to the health of pregnant women, especially during the Covid-19 pandemic, so knowing the possibility of abnormalities occur during pregnancy during a pandemic, making mothers feel more anxious.

The results showed that there was a relationship between family support and anxiety of pregnant women during the Covid-19 pandemic at the work area of the Banjar g Health Center Pandeglang. Support from family can also help pregnant women, maintain their psychological health condition, more receptive to physical changes and control emotions that arise. Pregnant women who have good family support can change their response to anxiety and reduce their anxiety. Meanwhile, pregnant women with poor family support can increase anxiety (Handayani, 2016). The latest study found that the third 
trimester pregnant women had a high level of social support, a medium level of risk perception to COVID19 and were susceptible to anxiety. Risk perception played a mediating role between social support and anxiety (Yue et al., 2021).

Family support is an external factor that affects the respondent's level of anxiety in pregnancy and facing childbirth. The results of this study are in line with research by Maimunah (2013) who found a relationship between family social support and maternal anxiety levels. It was found that support from the family affects the level of anxiety of pregnant women. This may be due to the importance of trusting pregnant women due to the increasing transmission of the Covid-19 disease. Pregnant women need support from their families to always maintain their health and participate in choosing the place of delivery and antenatal care during the Covid-19 pandemic.

The results showed that there was a relationship between health facilities and the anxiety of pregnant women during the Covid-19 pandemic in the work area of the Banjar Health Center Pandeglang. Based on the Minister of Health Regulation No. 97 of 2014 concerning health services for the period before pregnancy, during pregnancy, childbirth, and the period after giving birth, Article 14 paragraph 1 reads that delivery must be carried out in health care facilities. According to PP No. 61 of 2014 article 16 number 4 midwives can offer health services if health facilities are difficult to get because of geographical differences and the vehicle is impossible. According Shodiqoh \& Syahrul (2014), states that health services must be carried out equally throughout Indonesia, so that maternal health can be maintained and maternal and child mortality rates can be lowered.

Health facilities are the most important facilities that pregnant women must choose to determine pregnancy check-ups and give birth because during the Covid-19 pandemic, mothers can reduce their anxiety to carry out examinations and give birth at the health facilities that mothers choose. Usually, pregnant women are currently more anxious when visiting health facilities for fear of being exposed to the Covid-19 virus, so the health facilities that the mother chooses should comply with health protocols.

The results showed that there was no relationship between health information and the anxiety of pregnant women during the Covid-19 pandemic in the working area of the Banjar Pandeglang Health Center. Information from health workers a significant external factor for pregnant women. Based on the results of the study, it was found that 53 respondents were well informed. The role of health workers is needed to reduce the risk of adverse pregnancy. Health workers as educators play a role in carrying out guidance or counselling, especially those related to reproductive health, including overcoming anxiety in pregnancy. Although information from health workers was obtained well, it did not play a role in the level of anxiety of pregnant women. This may be due to the lack of assistance and the respondent's doubts about health workers.

\section{Conclusion}

Factors related to the anxiety of pregnant women during the Covid-19 pandemic in the Banjar Pandeglang Health Center work area in 2021 were knowledge, family support and health facilities. Therefore, it is hoped that pregnant women could pay more attention to their situation both physically and psychologically and ask their husband or family to always provide support, participate in maintaining pregnancy and preparing for childbirth and continue to comply with the health protocols to avoid Covid-19 virus.

\section{Acknowledgments}

The current article is extracted from Performance Assessment of Public Health Center and approved by 5 Community Health Centre in Berau District - East of Borneo. The authors would like to thank and appreciate all nurses and Leaders of Community Health Centre and head of health department in Berau District - East of Borneo.

\section{References}

Astria, Y., Nurbaeti, I., Rosidati, C. (2019). Hubungan Karakteristik Ibu Hamil Trimester III Dengan Kecemasan Dalam Menghadapi Persalinan di Poliklinik Kebidanan dan Kandungan Rumah Sakit X Jakarta. Majalah Keparawatan UNPAD, 10 (19), 38-48.

Astuti, Y., (2012), Hubungan Karakteristik ibu Hamil Primigravida Trimester ketiga dengan tingkat kecemasan di RSUD Pasar Rebo. Skripsi, Program Studi Sarjana Keparawatan Universitas Indonesia, Jakarta.

Hernanto, F., F. (2016). Pengetahuan Tentang Kehamilan, Dukungan Keluarga Dan Kecemasan Ibu Primigravida 
Trimester III, Jurnal Psikologi Indonesia, 5(3): 1-5.

Handayani, R. (2016). Faktor- Faktor Yang Berhubungan Dengan Tingkat Kecemasan Menjelang Persalinan Pada Ibu Primigravida Trimester III Di Wilayah Kerja Puskesmas Lubuk Budaya Padang Tahun 2012. Ners Jurnal Keperawatan, 11, 62- 71 .

Kemenkes R.I. (2020), Peraturan Menteri Kesehatan Republik Indonesia Nomor 9 Tahun 2020 Tentang Pedoman Pembatasan Sosial Berskala Besar Dalam Rangka Percepatan Penanganan Corona Virus Disease 2019 (Covid-19), Jakarta.

Maimunah, S., (2019). Kecemasan Ibu Hamil Menjelang Persalinan Pertama. Jurnal Humanity,5(1), 61-67.

Mappa, I., Distefano, F. A., \& Rizzo, G. (2020). Effects of coronavirus 19 pandemic on maternal anxiety during pregnancy: a prospectic observational study. Journal of Perinatal Medicine, 48(6), 545-550.

Masruroh., (2015). Pengaruh Kecemasan Ibu Terhadap Terhadap Proses Persalinan Kala 1 Fase Aktif Di BPS Atik Surahiati Surabaya, Jurnal Ilmiah Kesehatan, 8(2), 2-5.

Notoatmojo, S. (2018), Pendidikan dan Perilaku Kesehatan, Rineka Cipta, Jakarta.

Novitasari, T., Budiningsih, T.E., \& Mabruri, M.I. (2013). Keefektivan Konseling Kelompok Pra-Persalinan Untuk Menurunkan Tingkat Kecemasan Primigravida Menghadapi Persalinan. Jurnal Developmental and Clinical Psychology, 2 (2), 62-70.

Shahhosseini, Z., Pourasghar, M., Khalilian, A., \& Salehi, F. (2015). A Review of the Effect of Anxiety During Pregnancy on Children's Health. Journal Mater Sociomed, 27(3), 200-202.

Shodiqoh, E. R., \& Syahrul, F. (2014). Perbedaan Tingkat Kecemasan Dalam Menghadapi Persalinan Antara Primigravida dan Multigravida. Jurnal Berkala Epidemiologi, 2(1), 141-150.

UKOSS, (2020), UK Obstetric Surveillance System (UKOSS) study in context, UK.

WHOạ. (2020), Pencegahan dan pengendalian Infeksi (PPI) untuk Novel Coronavirus (COVID-19), WHO.

WHO $^{\mathrm{b}}$. (2020), Naming the coronavirus disease (COVID-19) and the virus that causes it. WHO.

Yue, C., Liu, C., Wang, J., Zhang, M., Wu, H., Li, C., \& Yang, X. (2021). Association between social support and anxiety among pregnant women in the third trimester during the coronavirus disease 2019 (COVID-19) epidemic in Qingdao, China: The mediating effect of risk perception. The International Journal of Social Psychiatry, $67(2), 120$. 